\title{
Pembakaran Gas Hasil Gasifikasi Biomassa di Premixed Gas Burner dengan Metoda 3D Computational Fluid Dynamic
}

\author{
Adi Surjosatyo \\ Departemen Teknik Mesin, Fakultas Teknik, Universitas Indonesia, Jakarta \\ E-mail: adi.surjosatyo@ui.ac.id; adi_sur@eng.ui.ac.id
}

\begin{abstract}
ABSTRAK
Dengan menipisnya cadangan minyak dunia dan masalah lingkungan yang diakibatkan oleh pembakaran bahan bakar fossil, maka diperlukan energi alternatif dalam mengatasi hal tersebut. Bahan bakar gas dari proses gasifikasi biomassa (producer gas) adalah salah satu energi alternatif yang dapat menggantikan bahan bakar fosil. Pemanfaatan producer gas untuk aplikasi pengeringan dan pemanasan boiler memerlukan suatu sistem gas burner yang dapat menghasilkan panas tinggi dan polusi rendah. Pada penelitian ini sebuah model gas burner berbahan bakar producer gas dilakukan pemodelan simulasi secara 3D menggunakan CFD. Simulasi dilakukan dengan menggunakan swirl gas burner dengan menggunakan conical flame stabilizer dan tanpa menggunakan conical flame stabilizer pada variasi kecepatan udara masuk tangensial $3 \mathrm{~m} / \mathrm{s}, 6 \mathrm{~m} / \mathrm{s}$ dan $9 \mathrm{~m} / \mathrm{s}$. Hasil simulasi menunjukkan penambahan conical flame stabilizer menghasilkan api yang lebih pendek dan stabil. Penambahan kecepatan udara memendekkan panjang api dan menurunkan temperatur api. Validasi eksperimental dilakukan pada gas swirl burner yang menggunakan conical flame stabilizer. Simulasi dan eksperiment menunjukkan hasil yang tidak jauh berbeda.
\end{abstract}

Kata kunci: CFD, producer gas, gas burner, conical flame stabilizer.

\begin{abstract}
The depletion of worlwide energy reservation and environmental issue caused by fossil fuel pollution urge mankind to find a suitable alternative energy to overcome this problem. Producer gas from biomass gasification is an example of an alternative energy that could substitute fossil fuel in a certain combustion operation. Using producer gas to generate heat needs gas burner system that can produce an effective gas flame with low emission gas. This study is using modeling and simulation of gas flame using 3D-CFD method. The gas burner model has two condition, namely, using conical flame stabilizer and without conical flame stabilizer, and the velocity tangential air supply is varied into three speed of $3 \mathrm{~m} / \mathrm{s}, 6 \mathrm{~m} / \mathrm{s}$ and $9 \mathrm{~m} / \mathrm{s}$, respectively. The result of this simulation shows the additional of conical flame stabilizer produces a shorter flame, increases flames stability and reduces $\mathrm{CO}$ emission. The experimental result shows a similar pattern compared with that of the simulation result.
\end{abstract}

Keywords: CFD, producer gas, gas burner, conical flame stabilizer.

\section{PENDAHULUAN}

Dengan menipisnya cadangan minyak dunia dan masalah lingkungan yang dihadapi oleh pembakaran dengan menggunakan bahan bakar fossil maka diperlukan energi alternatif dalam mengatasi hal tersebut. Gasifikasi biomassa adalah salah satu cara alternatif untuk menggurangi ketergantungan dari bahan bakar fosil. Proses gasifikasi biomassa akan mengahasilkan gas mampu bakar yaitu $\mathrm{CO}, \mathrm{CH}_{4}$, dan $\mathrm{H}_{2}$ yang dapat dimanfaatkan sebagai bahan bakar baik untuk mesin pembakaran dalam ataupun burner untuk memanaskan boiler.
Aplikasi pada boiler memerlukan suatu jenis burner tertentu yang dapat menghasilkan efisiensi pembakaran yang tinggi samping emisi $\mathrm{NO}_{\mathrm{x}}$ dan $\mathrm{CO}_{\mathrm{x}}$ rendah. Api yang dihasilkan dari reaksi pembakaran pada burner tersebut akan mengisi Combustion Chamber dan karakteristik api tersebut akan mempengaruhi panas yang dihasilkan.

Salah satu cara untuk mengetahui distribusi temperatur dan emisi yang dihasilkan dari proses pembakaran adalah menggunakan CFD (Computational Fluid Dynamic). CFD merupakan suatu analisis aliran fluida di dalam sistem dengan menggunakan metode algoritma numeric yang berbasis komputer. 
Beberapa penelitian simulasi pada gas burner telah dilakukan. Adi Surjosatyo dkk [1] melakukan penelitian simulasi 3D mengunakan CFD pada swirl gas burner dengan variasi sudut vane $20^{\circ}, 30^{\circ}$, dan $40^{\circ}$, fluida kerja yang digunakan adalah udara. Hasil penelitian menunjukkan semakin besar sudut swirl semakin meningkat kecepatan udara tangensial yang selanjutnya akan menyebabkan peningkatan stabiltas api jika terjadi proses pembakaran. Bode dkk [2] melakukan simulasi 2D menggunakan CFD dan model aliran turbulen RNG K- $\varepsilon$ pada swirl gas burner dengan kondisi tampa reaksi campuran gas $\mathrm{CH}_{4}$ dan udara untuk melihat fenomena pola percampuran pada aliran. Hasil penelitian menunjukkan model turbulen RNG K- $\varepsilon$ memberikan hasil yang memuaskan dalam memprediksi pola percampuran aliran. Hodor dkk, [3] melakukan simulasi 2-D Gasodynamyk burner dengan dua geometri berbeda untuk mendapatkan metode percampuran $\mathrm{CH}_{4}$ dan udara. Hasil penelitianya menunjukkan desain burner yang baik memiliki kontur tekanan keluar yang lebih besar dari kerugian tekanan pada flue gas melewati chamber. Chiummo dkk [4] melakukan penelitian simulasi 2D menggunakan CFD pada Duct Gas burner menggunakan bluff body berbahan bakar $\mathrm{CH}_{4}$. Hasil penelitian menunjukkan burner dengan sudut bluff body $60^{\circ}$ menunjukkan peningkatan kecepatan lebih baik dan stabilitas flame lebih baik.

Penelitian ini bertujuan mensimulasikan proses pembakaran pada swirl gas burner dengan menggunakan bluff body berbentuk conical (conical flame stabilizer) dan tanpa conical flame stabilizer pada beberapa variasi kecepatan tangensial udara masuk dan melakukan validasi eksperimen pada gas burner yang menghasilkan temperatur tinggi dan emisi $\mathrm{CO}$ rendah.

\section{METODE PENELITIAN}

Sebelum dilakukan simulasi terlebih membuat model 3 dimensi gas burner dengan menggunakan solid work. Prinsip kerja gas burner yang di simulasikan dapat dijelaskan sebagai berikut. Udara pembakaran masuk melalui saluran tangensial yang selajutnya melewati swirl. Producer gas masuk melewati saluran aksial dan bercampur dengan udara. Campuran udara dan producer gas selajutnya melewati conical flame stabilizer dan dibakar dalam ruang bakar (combustion chamber) untuk menghasilkan panas seperti yang diperlihatkan pada Gambar 1.

Dimensi system gas burner adalah sebagai berikut: saluran masuk bahan bakar dengan diameter $66 \mathrm{~mm}$ dan panjang $200 \mathrm{~mm}$. Saluran masuk udara tangensial dengan diameter $22 \mathrm{~mm}$ dan panjang $102 \mathrm{~mm}$. Burner dengan diameter daerah masuk $96 \mathrm{~mm}$, panjang $155 \mathrm{~mm}$ dan diameter daerah keluar $166 \mathrm{~mm}$. Ruang percampuran dengan diameter $166 \mathrm{~mm}$, panjang $102 \mathrm{~mm}$. Ruang bakar dengan panjang $952 \mathrm{~mm}$ dan dimeter 422 $\mathrm{mm}$. Swirl dengan, panjang $60 \mathrm{~mm}$, sudut kemiringan terhadap garis normal $30^{\circ}$ dan jumlah vane 8. Conical flame stabilizer berbentuk kerucut dengan diameter $30 \mathrm{~mm}$ dan panjang sisi $21 \mathrm{~mm}$

Model gas burner dari solid selajutnya dilakukan meshing menggunakan software Gambit. Type mesh yang digunakan adalah tetrahybrid seperti yang diperlihatkan pada Gambar 2.

Simulasi dilakukan menggunakan software Fluent. Model penyelesaian yang digunakan adalah:

- Tunak (steady state)

- Perpindahan panas

- Turbulensi k- epsilon RNG

- Perpindahan Senyawa (speces transport) atau Pembakaran gas

- Reaksi dihitung menggunakan model Eddy disipasi

Persamaan-persamaan yang digunakan pada model penyelesaian adalah persamaan konservasi massa, konservasi momentum, konservasi energi, Turbulensi RNG K-e dan Perpindahan senyawa (speces transport) masing-masing persamaan 1, 2, 3, 4 dan 5 di bawah ini.

$$
\frac{\partial \rho}{\partial t}+\nabla \cdot(\rho \vec{v})=S_{m}
$$

$\frac{\partial}{\partial t}(\rho \vec{v})+\nabla \cdot(\rho \vec{v} \vec{v})=-\nabla p+\rho \vec{g}+\vec{F}$

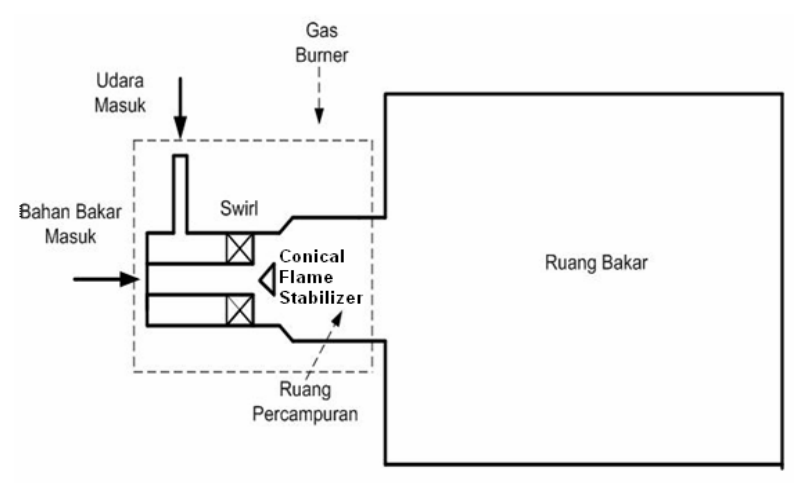

Gambar 1. Model Gas Burner dan Ruang Bakar

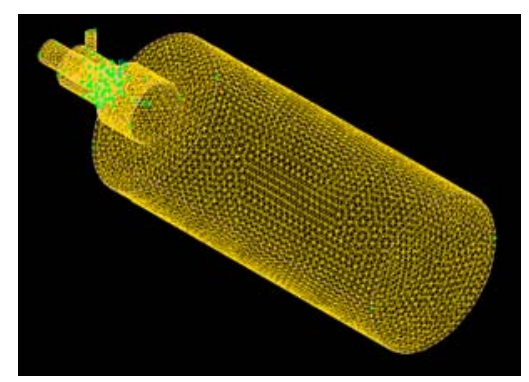

Gambar 2. Hasil Meshing 


$$
\begin{aligned}
& \frac{\partial}{\partial t}(\rho E)+\nabla \cdot(\vec{v}(\rho E+p))=-\nabla \cdot\left(\sum_{j} h_{j} J_{j}\right)+S_{h} \\
& \frac{\partial}{\partial t}(\rho k)+\frac{\partial}{\partial x_{i}}\left(\rho k u_{i}\right)=\frac{\partial}{\partial x_{j}}\left(\alpha_{k} \mu_{\mathrm{eff}} \frac{\partial k}{\partial x_{j}}\right)+G_{k}+G_{b}-\rho \epsilon-Y_{M}+S_{k} \\
& \frac{\partial}{\partial t}\left(\rho Y_{i}\right)+\nabla \cdot\left(\rho \vec{v} Y_{i}\right)=-\nabla \cdot \vec{J}_{i}+R_{i}+S_{i}
\end{aligned}
$$

Dimana $v$ vektor kecepatan $(\mathrm{m} / \mathrm{s}), \rho$ mass jenis gas gas $\left(\mathrm{kg} / \mathrm{m}^{3}\right), S_{m}$ adalah Sorce Term akibat penambahan masa ke phasa yang kontinuis dari dispesrsed pasa ke dua, $P$ tekanan statik $(\mathrm{Pa}), \vec{\tau}$ merupkan tensor tegangan $(\mathrm{Pa}), \rho \vec{g}$ gaya grafitasi bodi (N), $\vec{F}$ gaya ekternal bodi (N), $E$ entalpi (J/kg), $h$ enthalfi senyawa $(\mathrm{J} / \mathrm{kg}), J_{i}$ laju aliran massa difusitas senyawa $i\left(\mathrm{~kg} / \mathrm{m}^{2} \mathrm{~s}^{2}\right), S_{h}$ source term akibat panas reaksi, $k$ turbulence kinetik energi $\left(\mathrm{m}^{2} / \mathrm{s}^{2}\right), u$ $\operatorname{kecepatan}(\mathrm{m} / \mathrm{s}), \quad \mu_{\text {eff }}$ viskositan dynamik efektif (kg/ms), $G_{k}$ pembangkit turbulen kinetik energi akibat gradien kecepatan tengah, $G_{b}$ pembangkit turbulen kinetik akibat buoyancy, $\varepsilon$ laju turbulen disipasi $\left(\mathrm{m}^{2} / \mathrm{s}^{3}\right), \quad Y_{m}$ pengaruh fluktuasi dilatasi turbulen kompresible terhadap laju disipasi, $S_{k}$ source term yang ditentukan pengguna, $Y_{i}$ fraksi massa masing-masing senyawa, $R_{i}$ adalah laju produksi bersih senyawa $i$ oleh reaksi kimia $\left(\mathrm{kg} / \mathrm{m}^{3} \mathrm{~s}^{2}\right), S_{i}$ adalah source term akibat penambahan dari fase tertentu.

Dengan mengasumsikan kondisi tunak maka komponen perubahan menurut waktu ( $/ / \partial \mathrm{t})$ pada persamaan di atas dihilangkan. Setelah melakukan pemodelan proses untuk simulasi maka selanjutnya dilakukan penentuan kondisi batas simulasi yaitu:

1. Komposisi fraksi massa gas pada producer gas

$$
\begin{aligned}
\mathrm{CO} & =25 \% \\
\mathrm{H}_{2} & =12 \% \\
\mathrm{CH}_{4} & =1,5 \% \\
\mathrm{CO}_{2} & =10 \% \\
\mathrm{~N}_{2} & =51,5 \%
\end{aligned}
$$

2. Kecepatan producer gas sebesar $1 \mathrm{~m} / \mathrm{s}$

3. Kecepatan injeksi udara tangensial, divariasikan mulai dari $3 \mathrm{~m} / \mathrm{s}, 6 \mathrm{~m} / \mathrm{s}, 9 \mathrm{~m} / \mathrm{s}$.

4. Temperatur producer gas sebesar $200^{\circ} \mathrm{C}$ dan temperatur udara tangensial sebesar $27^{\circ} \mathrm{C}$.

Setelah mendapatkan hasil simulasi maka selanjutnya dilakukan pembuatan dan pengujian swirl gas burner dengan conical flame stabilizer. Pengujian dilakukan pada Laboratorium Gasifikasi Termodinamika Depertemen Teknik Mesin, Fakultas Teknik, Universitas Indonesia. Hasil pengujian kemudian dibandingkan dengan hasil simulasi sebagai bahan validasi. Sistim gasifikasi biomassa dan unit gas burner yang digunakan seperti pada Gambar 3 dan 4. Distribusi suhu pada ruang bakar diukur menggunakan dua termokopel type K (cromnel dan alumnel) yang dipasang pada ruang bakar secara aksial dengan jarak masing $0.3 \mathrm{~m}$ dan $0,6 \mathrm{~m}$ dari bagian pangkal ruang bakar. Pengukuran komposisi CO dilakukan pada jarak aksial 0,3 m dari bagian pangkal ruang bakar dan jarak radial $0,1 \mathrm{~m}$ dari pusat ruang bakar menggunakan SCX gas analyzer.

\section{HASIL DAN PEMBAHASAN}

\section{Pengaruh Variasi Kecepatan Udara Masuk}

Semakin meningkatnya kecepatan udara masuk akan mengurangi temperatur dan memendekkan flame baik menggunakan conical flame stabilizer maupun tanpa conical flame stabilizer seperti yang diperlihatkan pada Gambar 5,6,7,8,9 dan 10. Hal ini dikarenakan semakin meningkatnnya jumlah udara maka akan menambah udara lebih (excess air) pembakaran dengan perbandingan udara bahan bakar (A/F ratio) 1,2; 2,4 dan 3 untuk untuk kecepatan udara masing- masing $3 \mathrm{~m} / \mathrm{s}, 6 \mathrm{~m} / \mathrm{s}$ dan 9 $\mathrm{m} / \mathrm{s}$. Peningkatan exess air pembakaran menyebabkan banyaknya oksigen dan nitrogen yang tidak ikut dalam proses pembakaran yang selanjutnya menyerap panas hasil proses pembakaran. Penyerapan panas oleh nitrogen dan oksigen ini mengakibatkan temperatur yang dihasilkan oleh proses pembakaran menjadi rendah.

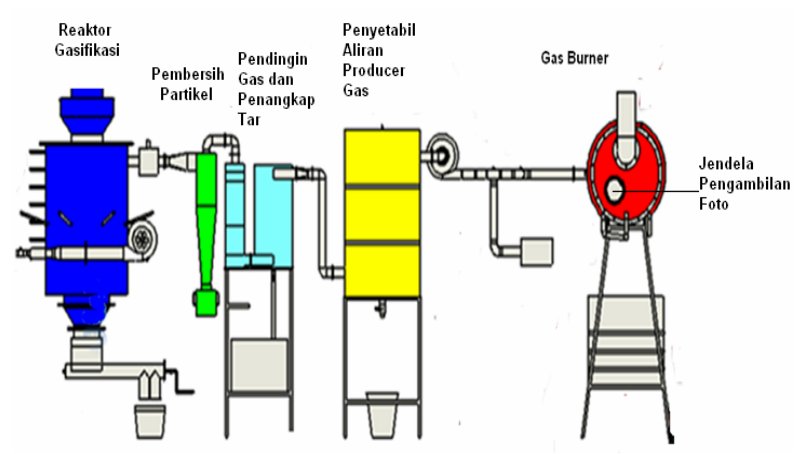

Gambar 3. Eksperimental Set up Unit

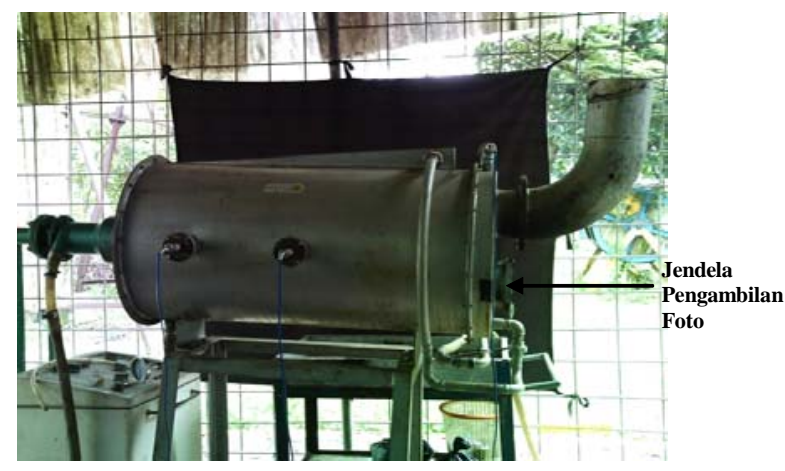

Gambar 4. Unit Gas Burner 


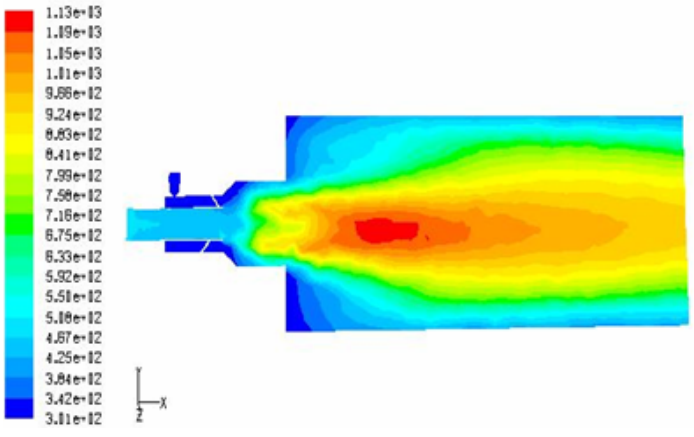

Gambar 5. Kontur Distribusi Temperatur Kecepatan 3m/s tanpa Conical Flame Stabilizer

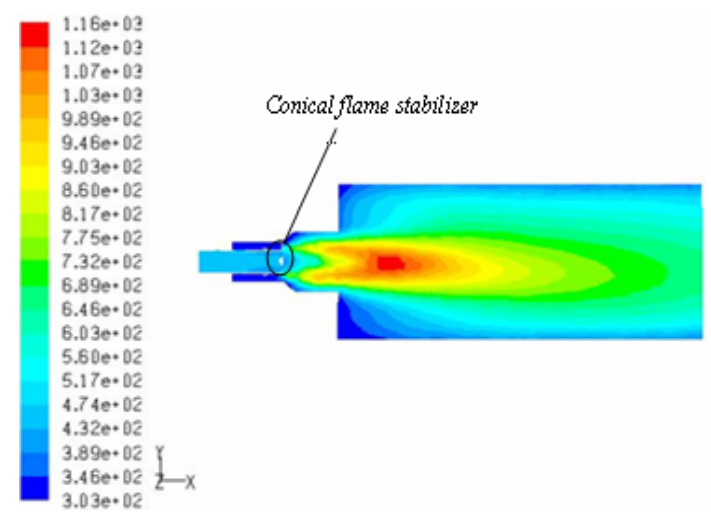

Gambar 6. Kontur Distribusi Temperatur ( $\left.{ }^{(} \mathrm{K}\right)$ Kecepatan 3m/s dengan Conical Flame Stabilizer

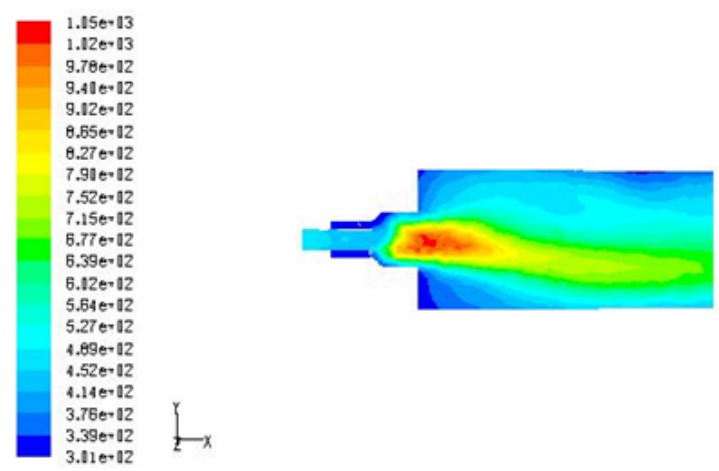

Gambar 7. Kontur Distribusi Temperatur (0K) Kecepatan 6 m/s tanpa Conical Flame Stabilizer

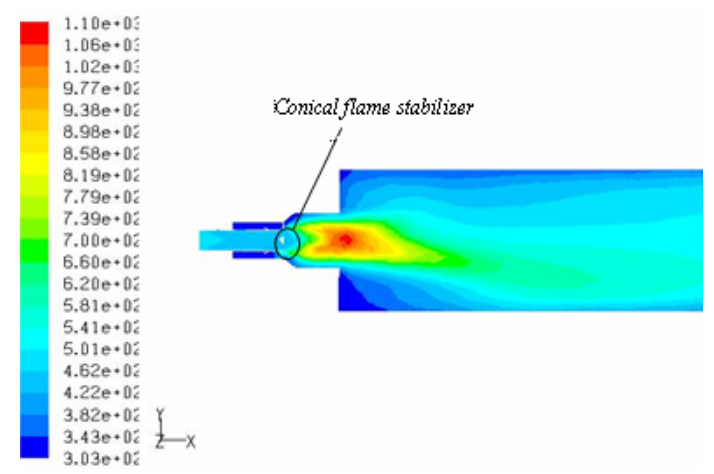

Gambar 8. Kontur Distribusi Temperatur ( $\left.{ }^{(} \mathrm{K}\right)$ Kecepatan 6 m/s dengan Conical Flame Stabilizer

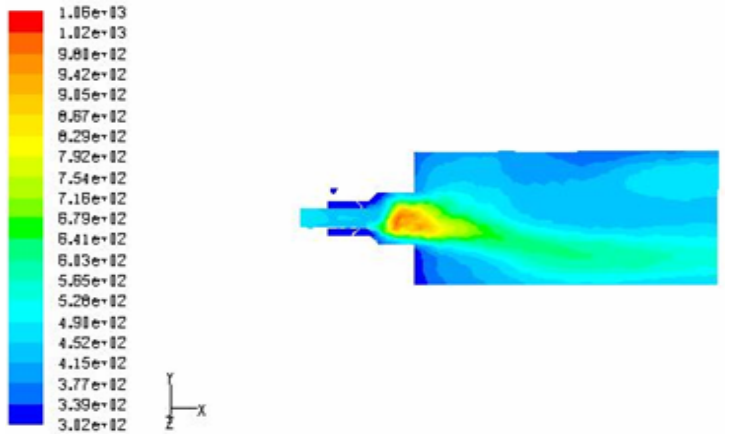

Gambar 9. Kontur Distribusi Temperatur ( $\left.{ }^{0} \mathrm{~K}\right)$ Kecepatan 9 m/s tanpa Conical Flame Stabilizer

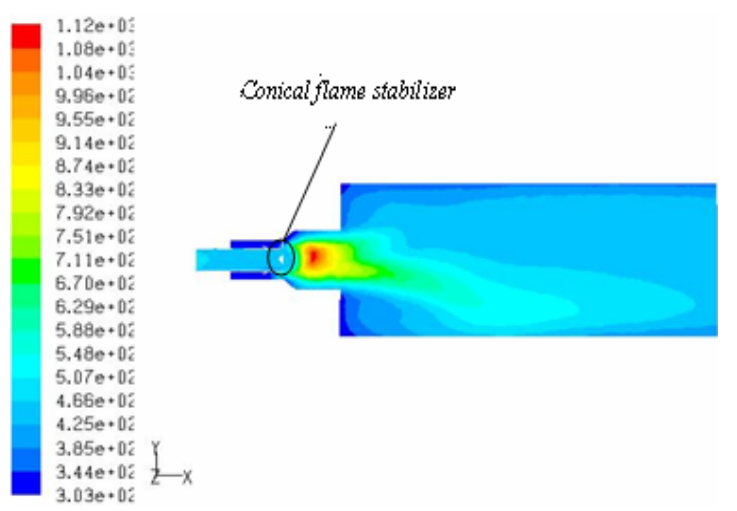

Gambar 10. Kontur Distribusi Temperatur $\left({ }^{0} \mathrm{~K}\right)$ Kecepatan 9 m/s dengan Conical Flame Stabilizer

Peningkatan kecepatan udara, seperti di Gambar 7, 8, 9, dan 10 menunjukkan telah menjauhkan temparatur maksimum api dari bagian atas burner baik tanpa conical flame stabilizer maupun dengan conical flame stabilizer seperti pada Gambar 11 dan 12. Hal tersebut diakibatkan oleh semakin tingginya kecepatan udara di dalam ruang bakar yang menyebabkan adanya udara berlebih dan menghasilkan intensitas turbulen yang lebih besar. Semakin besar intensitas turbulen, waktu percampuran yang terjadi akan semakin lama sebelum penyalaan.

Efek peningkatan kecepatan tangential udara masuk, mengakibatkan pula perubahan pola api yang mengikuti arah pusaran tubulensi, seperti cenderung kearah bawah atau lidah api melengkung kebawah. Ini sesungguhnya bentuk api yang berputar, kemudian karena potongan memanjang menunjukkan seolah-olah api hanya melengkung ke bawah.

Hasil simulasi sebenarnya tidak mengambarkan bentuk api akan tetapi mengambarkan distribusi suhu yang terjadi hasil proses pembakaran. Pada kontur temperatur hasil simulasi memang terlihat sedikit sekali perbadaan jarak antara temperatur maksimum yang dihasilkan burner menggunakan conical flame stabilizer dan tanpa conical flame stabilizer akan tetapi jika dikeluarkan dalam bentuk grafik bisa terlihat dengan jelas seperti pada Gambar 11 dan 12. 


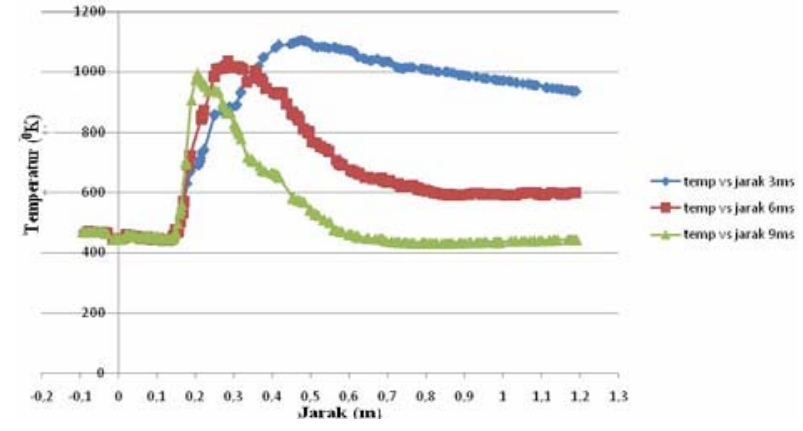

Gambar 11. Distribusi Temperatur Berdasarkan Jarak dari Pangkal Ruang Bakar tanpa Conical Flame Stabilizer

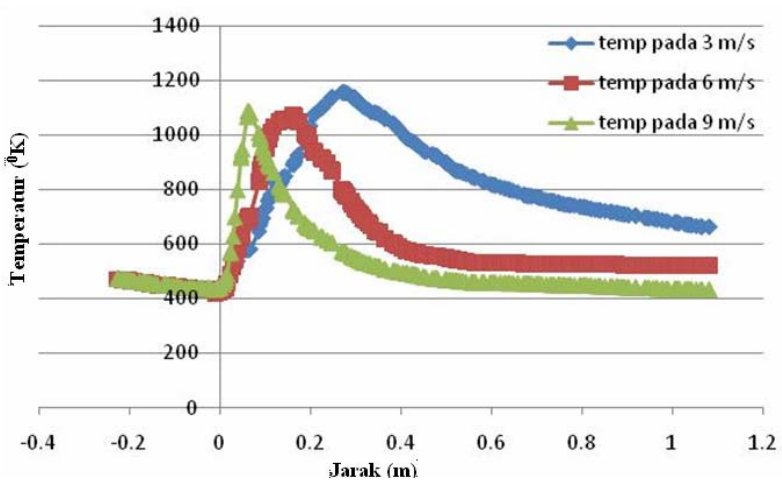

Gambar 12. Distribusi Temperatur Berdasarkan Jarak dari Pangkal Ruang Bakar Menggunakan Conical Flame Stabilizer

Pada simulasi 3D dimensi kita tidak mengasumsikan dua belahan sama dan simetris akan tetapi berdasarkan kondisi real yang didapat pada simulasi sehingga kontur distribusi temperatur yang dihasilkan tidak simetris.

\section{Pengaruh Penambahan Conical Flame Stabilizer}

Penambahan conical flame stabilizer akan memberikan pengaruh pada bentuk api khususnya pada kecepatan $3 \mathrm{~m} / \mathrm{s}$ seperti pada Gambar 5 dan 6 terlihat perbandingan bentuk api antara pengunaan conical flame stabilizer dan tanpa conical flame stabilizer, penambahan conical flame stabilizear akan menghasilkan suatu aliran balik (reverse flow) pada aliran yang menghasilkan central recirculation zone (CRZ) menyebabkan suatu konsentrasi percampuran antara bahan bakar dan udara yang lebih sempurna. Sehingga pada saat terjadi pembakaran maka maka api akan lebih pendek dan kurus akan tetapi temperatur yang dihasilkan lebih tinggi karena udara dan bahan bakar bercampur lebih sempurna. Dengan kata lain, kecepatan kinetik pembakaran lebih tinggi dengan meningkatnya efek pusaran (IRZ dan CRZ).

Temperatur maksimum untuk masing-masing kecepatan udara pembakaran dengan mengguna- kan conical flame stabilizer lebih tinggi dikarenakan dengan pengunaan conical flame stabilizer akan meningkatkan daerah resirkulasi (recirculation zone) yang dapat meningkatkan laju percampuran bahan bakar dengan udara sehingga pembakaran lebih sempurna serta mengurangi panjang api dan dapat mengurangi panjang combustor [5].

Pengaruh penambahan conical flame stabilizer juga dapat dilihat dari kandungan karbon monoksida yang dihasilkan dalam fraksi mol. Kandungan karbon monoksida tanpa menggunakan conical flame stabilizaer lebih besar seperti yang diperlihatkan pada Gambar 13 dan 14, hal ini dikarenakan penambahan conical flame stabilizer akan lebih meningkatkan percampuran bahan bakar sehingga pembakaran lebih sempurna.

\section{Perbandingan Hasil Simulasi dan Eksperimen}

Berdasarkan informasi simulasi yang kita dapat burner dengan conical flame stabilizer lah yang lebih baik ditinjau dari distribusi suhu dan CO yang dihasilkan. Sehingga validasi terhadap ekseperimen dilakukan hanya menggunakan burner menggunakan conical flame stabilizer.

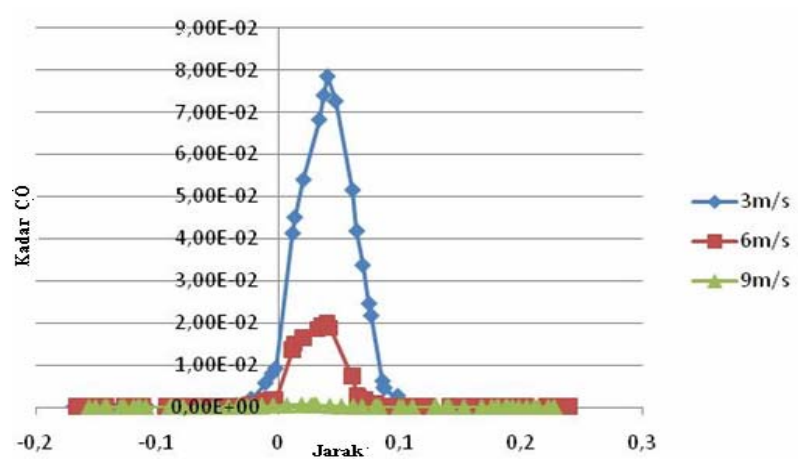

Gambar 13. Komposisi CO (mol) pada Arah Diameter Ruang Bakar pada Jarak 0,3 m dari Pangkal Ruang Bakar tanpa Conical Flame Stabilizer

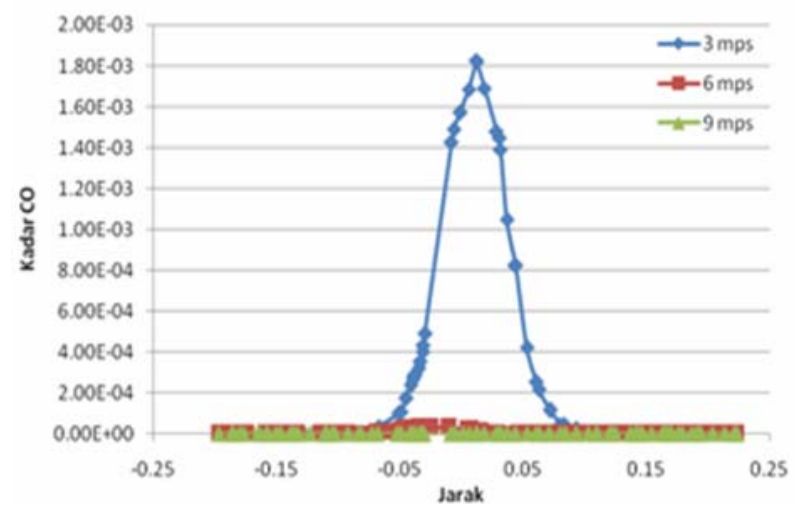

Gambar 14. Komposisi CO (mol) dalam Arah Ruang Bakar ada Jarak 0,3 m dari Pangkal Ruang Bakar dengan Conical Flame Stabilizer 


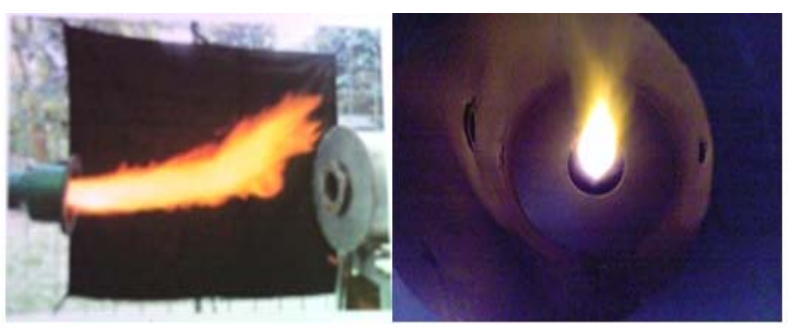

Gambar 15. Bentuk Api dengan Conical Flame Stabilizer di Luar dan Dalam Ruang Bakar

Perbandingan hasil eksperimen dan simulasi menunjukkan temperatur hasil eksperimen dibawah nilai dari yang diprediksi untuk berbagai kecepatan seperti yang diperlihatkan oleh Tabel 1. Hal ini dikarenakan adanya kerugian panas akibat radiasi dalam ruang bakar akan tetapi hasil ini simulasi cukup memuaskan.

Komposisi CO hasil simulasi dan Eksperimental diperlihatkan pada Tabel 2. Untuk kecepatan $3 \mathrm{~m} / \mathrm{s}$ terlihat nilai $\mathrm{CO}$ tidak terlalu jauh berbeda dengan hasil simulasi maksimum. Pada kecepatan di atas 3 $\mathrm{m} / \mathrm{s}$ nilai $\mathrm{CO}$ tidak dapat terdeteksi oleh alat ukur karena nilainya sangat kecil.

Api yang dihasilkan oleh gas burner dengan menggunakan conical flame stabilizer didalam ruang bakar melalui jendela pengambilan foto dan di luar ruang bakar diperlihatkan pada Gambar 15. Bentuk api melengkung ke atas pada eksperimen karena pengaruh pergerakkan arah tekanan udara.

\section{KESIMPULAN}

Penggunaan conical flame stabilizer pada gas burner akan menyebabkan panjang api lebih pendek, suhu lebih api tinggi, api lebih stabil dan kandungan $\mathrm{CO}$ yang lebih rendah. Validasi pada gas burner menggunakan conical flame stabilizer menunjukkan hasil eksperimen dan simulasi hampir mendekati hal terlihat pada distribusi temperatur, komposisi CO dan bentuk api dalam ruang bakar. Dengan bantuan sofware Fluent dapat mempermudah dalam desain dan pemilihan sistem gas burner terutama untuk memprediksi suhu dan emisi CO yang dihasilkan dari suatu sistem gas burner.

\section{Ucapan Terima Kasih}

Ucapan terima kasih ini ditujukan kepada mahasiswa Pasca Sarjana Fajri Vidian dan mahasiswa Tingkat Akhir yaitu Yudho Danu, Fiki, Razi dan Adam yang telah membantu melaksanakan Experimen dan Simulasi sehingga selesainya studi ini. Ucapan terima kasih juga kepada DRPM UI yang telah mendanai studi ini hingga selesai.

\section{DAFTAR PUSTAKA}

1. Surjosatyo, Adi., Nasir, Farid., "A CFD based ISOTHERMAL Model of Swirl Burner Development", The $14^{\text {th }}$ International Symposium on Transport Phenomena, Bali, Indonesia, 6-10 July, 2003.

2. Bode, Florin, Hodor, Victor, "Numerical Investigation on A Swirl Burner with Internal Flue Recirculation". $3^{\text {nd }}$ Workshop on Vortex dominated Flow, Timiosoara, Rumania, 1-2 June, 2007.

3. Hodor, Victor., Bode, Florin., "CFD First Prediction In Designing A $50 \mathrm{Kw}$ Swirling Burner Within Its Combustion Chamber", $3^{\text {nd }}$ Workshop on Vortex dominated Flow, Timiosoara, Rumania, 1-2 June 2007.

4. Chimno, G., Di Nardo, A., "Parametrical Analysis on a Exhaust Gas-Methane-Burner in Steady State Condition: A Post Combustion Case", Departement of Mechanical Engieneering and Energetic University of Naples, Italy, 2006.

5. Bhoi, PR., Channiwula, S.A., "Emission Characteristic and axial Flame Temperature Distribution of Producer Gas Fired Premixed Burner, International Journal Biomass \& Bioenergy", Vol 33, 2009, hal. 469-477.

6. Fluent Inc., Fluent 6.3 “User's Guide". Fluent Incoporated, Lebanon.

7. Kuo, K.K., Principles of Combustion, John Wiley and Sons, New York, 2006.

Tabel 1. Perbandingan Hasil Eksperimental dan Simulasi untuk Temperatur

\begin{tabular}{ccccccc}
\hline Jarak aksial dari & \multicolumn{5}{c}{ Temperatur $(0 \mathrm{~K})$} \\
\cline { 2 - 6 } pusat ruang & \multicolumn{2}{c}{ Kecepatan $3 \mathrm{~m} / \mathrm{s}$} & \multicolumn{2}{c}{ Kecepatan $6 \mathrm{~m} / \mathrm{s}$} & \multicolumn{2}{c}{ Kecepatan $9 \mathrm{~m} / \mathrm{s}$} \\
\cline { 2 - 7 } bakar $(\mathrm{m})$ & Eksperimental & Simulasi & Eksperimental & Simulasi & Eksperimental & Simulasi \\
\hline 0.3 & 1078 & 1128 & 698 & 751 & 501 & 533 \\
0.6 & 769 & 815 & 488 & 528 & 412 & 454 \\
\hline
\end{tabular}

Tabel 2. Perbandingan Hasil Eksperimental dan Simulasi untuk Komposisi CO

\begin{tabular}{|c|c|c|c|c|c|c|c|}
\hline \multirow{3}{*}{$\begin{array}{c}\text { Jarak aksial } \\
\text { dari pusat } \\
\text { ruang bakar }(\mathrm{m})\end{array}$} & \multirow{3}{*}{$\begin{array}{c}\text { Arah diameter } \\
\text { dari pusat ruang } \\
\text { bakar }(m)\end{array}$} & \multicolumn{6}{|c|}{ Komposisi CO (fraksi mol) } \\
\hline & & Kec & $3 \mathrm{~m} / \mathrm{s}$ & \multicolumn{2}{|c|}{ Kecepatan $6 \mathrm{~m} / \mathrm{s}$} & \multicolumn{2}{|c|}{ Kecepatan $9 \mathrm{~m} / \mathrm{s}$} \\
\hline & & Eksperimental & Simulasi & Eksperimental & Simulasi & Eksperimental & Simulasi \\
\hline 0,3 & 0,1 & $9 \times 10^{-4}$ & $1.82 \times 10^{-3}$ & Tidak terukur & $2 \times 10^{-7}$ & Tidak terukur & $1,23 \times 10^{-9}$ \\
\hline
\end{tabular}

